\title{
Malignant lymphoma incidence and HIV-related lymphoma subtypes in the Western Cape of South Africa, 2002-2009
}

\author{
E Akin Abayomi ${ }^{1,3}$, Avril Sommers ${ }^{1}$, Ravnit Grewal', Gerhard Sissolak , Fatima Bassa ${ }^{1}$, Deborah Maartens ${ }^{1}$, \\ Peter Jacobs' ${ }^{1}$, Cristina Stefan', Leona W Ayers ${ }^{2,3^{*}}$ \\ From $12^{\text {th }}$ International Conference on Malignancies in AIDS and Other Acquired Immunodeficiencies \\ (ICMAOI)
}

Bethesda, MD, USA. 26-27 April, 2010

\section{Background}

The incidence of malignant lymphomas (ML) in the Western Cape, a province of South Africa (SA), with a population of 5 million and an estimated HIV prevalence of $15 \%$ (census report 2002) has not been previously documented. Highly active antiretroviral therapy (HAART) was introduced into the public patient sector in 2004, with $28 \%$ estimated coverage by 2007 (UNAIDS/WHO 2008). People living with HIV (PLWH) have 60-200 times increased risk of developing HIVrelated lymphoma (HRL). Therefore, based on HIV prevalence, HRL would be expected to increase but is undocumented.

\section{Materials and methods}

We reviewed all patients diagnosed with ML from the Tygerberg Academic Hospital catchments area in the Western Cape of SA for years 2002-2009. In this timeframe 606 cases of ML were identified, of which 488 were HIV-negative and $118 \mathrm{HIV}$-positive. ML were subtyped according to WHO classification (2008) based on cell or tissue morphology and molecular and immunophenotypic platforms.

\section{Results}

ML cases increased each year from 2002 to 2005 and remain elevated in both the HIV-negative and HIV-positive patients through 2009. HRL increased from $5 \%$ in 2002 to $30 \%$ in 2009 with a profile of subtypes differing

\footnotetext{
* Correspondence: ayers.1@osu.edu

${ }^{2}$ Department of Pathology, The Ohio State University, Columbus, OH, USA Full list of author information is available at the end of the article
}

from the HIV-negative cases. ML subtypes of HIV-negative (488) and HIV-positive (118) cases are shown in Table 1.

\section{Conclusions}

ML cases increased from 2002 to 2009 including a dramatic increase in HRL, currently at $29 \%$ of all cases. This changing pattern of subtypes in PLWH presents new challenges to histopathology diagnosis as well as a clinically more therapeutically difficult patient population. Burkitt lymphoma, the most common HRL, is among emerging subtypes, along with plasmablastic lymphoma, not previously seen in this geographic region. We anticipate the continued rise in HRL cases as PLWH live longer with HAART. Emergence of more

Table 1 Percentages of ML subtypes by HIV status.

\begin{tabular}{lll}
\hline Subtype & $\% H I V-$ & $\% H I V+$ \\
\hline Burkitt lymphoma & & 35 \\
Diffuse large B-cell lymphoma & 44 & 33 \\
Plasmablastic lymphoma & & 16 \\
Follicular lymphoma & 12 & \\
Hodgkin's lymphoma & 11 & 5 \\
Small cell lymphoma & 4 & 1 \\
Mucosa-associated lymphoid tissue (MALT) & 4 & 1 \\
Anaplastic large cell lymphoma & 3 & 3 \\
Marginal zone lymphoma & 3 & \\
Cutaneous T-cell lymphoma & 3 & \\
T-cell lymphoma & 2 & 1 \\
Primary effusion lymphoma and Castleman's disease & & 2 \\
Other & 13 & 4 \\
Total & 100 & 100 \\
\hline
\end{tabular}


aggressive lymphoma subtypes inevitably poses a major strategic health concern in the region. We participate in the Sub-Saharan Africa Lymphoma Consortium [http:// www.ssalc.org] to expand the understanding of HRL in this region of the world.

\section{Acknowledgements}

This article has been published as part of Infectious Agents and Cancer Volume 5 Supplement 1, 2010: Proceedings of the $12^{\text {th }}$ International Conference on Malignancies in AIDS and Other Acquired Immunodeficiencies (ICMAOI).The full contents of the supplement are available online at http://www.biomedcentral.com/1750-9378/5?issue=S1.

\section{Author details}

'Division of Haematology, Stellenbosch University, Cape Town, South Africa. 2Department of Pathology, The Ohio State University, Columbus, OH, USA.

${ }^{3}$ Sub-Saharan Africa Lymphoma Consortium.

Published: 11 October 2010

doi:10.1186/1750-9378-5-S1-A53

Cite this article as: Abayomi et al: Malignant lymphoma incidence and HIV-related lymphoma subtypes in the Western Cape of South Africa, 2002-2009. Infectious Agents and Cancer 2010 5(Suppl 1):A53.

\section{Submit your next manuscript to BioMed Central} and take full advantage of:

- Convenient online submission

- Thorough peer review

- No space constraints or color figure charges

- Immediate publication on acceptance

- Inclusion in PubMed, CAS, Scopus and Google Scholar

- Research which is freely available for redistribution

Submit your manuscript at www.biomedcentral.com/submit 